\title{
The Impact on College Education in Big Data Era
}

\author{
Wang Ke \\ School of Economy and Management \\ Shenyang Aerospace University \\ Shenyang City, China
}

\begin{abstract}
Due to the development of information technology and Internet, the huge data impacts on all walks of life in the world. In this case, the way of thinking and the living habit change a lot, which also happens in the education industry. As of the support from big data, a new revolution has come to the education industry; in this revolution, colleges and universities face both opportunities for development and serious challenges because of the large amount, the fast speed and effectiveness of the data. Leaders should consider how to face the impact and regulate all sorts of work in colleges and universities by the means of establishing big database and building the big data awareness. The article mainly analyzed the impact on colleges and universities from big data era.
\end{abstract}

Keywords-Big data era; Colleges and universities; Education; Revolution; Data

In the construction of college education, the current popular information technology is indispensable. From the perspective of students, teachers or schools, there is a large amount of information, which has complex structure, fast generation frequency, and big impact on the construction of colleges and universities both in mind and in the material. The popularity of smart phones, computers and cloud computing makes the data acquisition much easier.

\section{BIG DATA ERA}

After proposing the concept of big data era by McKinsey, Victor from Britain specially published a book dedicated to elaborate the big data era, and the word was used more and more afterwards; besides China, it had a profound impact on the world. Big data refers to the large amount of information that is impossible to be managed by common software; the information will be generated in daily activities, and people can predict things by analyzing the relationship among the big data; big data has the characteristics of large amount, fast speed, low value density and more kinds, so the sample space is large, the requirement of accuracy is reduced, the process is ignored and only results matter; the first two can be easily understood because of the huge data; as of the third characteristics, during the analysis and prediction, if the amount of information is large enough, people can directly explore the nature of things and skip the deducing process, which is consistent with the characteristics of the big data era. In this revolution, big data changes not only the human mind, but also the life style, work content and so on. Education industry is changed in this revolution, for example, various education platform, flipped classroom and intelligent introductory courses are all the products of this environment.

The transformation of colleges and universities in big data era is inevitable; the characteristics of current colleges and universities is to output the universal talents in batches and cultivate the talents with enclosed classroom and definitive knowledge. In the present saturated market, society needs more specialized talents, and the cultivation mode of big data era satisfied this in a good way. The open classroom focuses on the individuality and liberalization of the students, so the content tends to be consistent with actual needs.

\section{IMPACT ON THE COLLEGE EDUCATION IN BIG DATA}

$$
\text { ERA }
$$

\section{A. Impact on teachers}

In general, the coming of big data era is a good thing. Teachers and students can get more comprehensive knowledge through more channels. What's more, except a small part of paid data, most of the data is for free, which is a good news for teachers who want to enrich their knowledge reserves and abilities. The development of big data era gives the teachers more teaching content and methods, for example, the teaching platform mentioned above. Teachers can communicate with the students face to face by forums or software so as to increase the diversity of teaching.

Every coin has two sides. The channel for information access and the amount of information has increased, but the time for acquiring knowledge should extend. Teachers and students can acquire information at the same time; compared with teachers, students can master the smart machines quickly, which is not good for teachers; our teachers are relatively older and unable to obtain teaching resources as they would wish, which is the weakness. The thinking of students becomes more picky after baptism of numerous information, which puts forward higher request for teachers, and teachers will be weeded out sooner or later if they stick to the past teaching methods. Big data era has put forward higher requirements for teachers, who also face great challenge and fierce competition, so teachers need to change their 
mind and improve their teaching level by taking part in all kinds of training. To some extent, this is a good thing for teachers as the left teachers would be with unique abilities. Under great pressure of competition, teachers will step up their learning and make great efforts to improve the overall teaching level of colleges and universities.

\section{B. Impact on students}

Compared to the teachers, the emergence of the big data era also has good and bad effects, but there is no fierce competition among them, which is good news. On the teaching content, students can choose their favorite courses because of the opening of data networking courses, the popularity of handset and computer makes it easier for students to look up data and solve the problems by various media. What's more, teachers would refine the teaching content in order to become outstanding in the competition, which will definitely increase the students' learning interest and enhance learning effect.

Compared with the teaching content, the change of teaching mode is obviously freer as it changes the learning style of the students and liberates the students from the enclosed classroom; the methods, location and time for learning are all changed, and free learning becomes the mainstream, which to some extent is a kind of brand-new reform of the education industry. College students have more rights to select the courses on their own, so they can select the learning resource through comparative thinking. However, this phenomenon requires an adjustment period; students have developed the dependence of teachers or fixed arrangement under the limitation of traditional education in the past for a long time; the relationship is terminated in the big data era, but quite a part of the students feel lost when they choose; many students will randomly choose content in this situation and waste lots of time due to no goal, which is the problem of hard choice. The problem of many options is that students may select as many courses as they are interested in, without correct understanding of their learning situation and definite plans; regardless of the unreasonable time arrangement, it is hard to guarantee the good results of each course.

\section{Impact on the college campus}

The impacts on teachers and students in big data era were discussed above, however, as liquidity elements, the two finally are attributed to campus. Because of information technology, campus is not confined to a region, and becomes the academic platform with inclusiveness, technicality and freedom, where students and teachers can exchange their ideas. The information technology makes all the schools in the world as a whole; the special courses of each school can be previewed on the internet, and students can leave a message following the course for discussion. The words mentioned above is the general concept, to be specific, the big data era has improved the teaching concept, teaching content, teaching process, teaching mode and teaching evaluation of colleges and universities.
First, in terms of teaching idea, the concept of cultivating labor-type talents in batch is transformed into the view of advocating the freedom of thought, cultivating talents with organizing ability, competitive ability and rationality, which is in accordance with the pursue of present college students; in terms of teaching content, the explanation of rigid contents in the textbook are changed into collecting latest professional information while explaining the basic knowledge; related activities are arranged for the students to understand the contents of the course so as to lay the foundation for later work;

With regard to teaching process, the greatest change is the teaching relationship between teachers and students, which breaks the unequal status of teachers and students; students become the master of the classroom, and teachers act as the guide and partner; the teachers and students learn from each other and make progress together, and the communication relationship among student-student and teacher-teacher is improved; because of the use of network, the current social media make up the shortcomings of previous backward communication means; in this two communication relationship, students get along with each other longer, have more common topics and communicate much easier;

In terms of teaching model, the teaching media are no longer just limited to the blackboard, textbooks and lecture from teachers on the platform; the application of multimedia system has added science for the teaching activity; compared with the monotonous voice of the teacher and words in the textbook, multimedia contains more information by using various media, and students are glad to accept this kind of teaching mode; although the tools have been changed, the nature of the teaching is still the same; the knowledge evolves from era, and then the change of big classroom; the network teaching platform is now increasingly popular as well as the small class, private one-on-one, and more than one teacher in one class, which appears to be more professional in training talents;

There are some changes about the teaching evaluation due to the impact of big data era. At present, the popular way of evaluating teachers is to set questionnaires or online evaluation, and these ways have great limitations due to lower validity as students have concerns about the final test evaluation or the teachers to be evaluated are their counselor; moreover, there are fewer evaluations to students from teachers; under the influence of big data era, the improved evaluation methods are to establish evaluation model by collecting and analyzing the information exchanged, which is more scientific and reasonable and can make evaluation to both sides.

\section{Impact on the thinking and construction}

\section{management in colleges and universities}

Because of the large volume and quick speed in big data era, it's difficult for colleges and universities to adapt to the data scale. The current data processing methods have defects due to the current continuous various professional data; the passive data processing 
can lead to the outflow of important data, especially the regular clear of data, which has severe destruction to the data. The way of processing data should be changed; change the mind and understand the big data era correctly. In the construction process of colleges and universities, the data to be collected is accumulated or investigated through long time by grass-roots organizations; the investigated data are real-time, but the analysis of these data is lagging, which is very serious under the background of big data era.

\section{SOME PROPOSALS TO STRENGTHEN THE TEACHING}

\section{IN COLLEGES AND UNIVERSITIES}

\section{A. Set up platform for data management}

Under the tide of big data era, the collection, processing and analysis of the data have become more and more important, which requires a special platform to process data, by which people can strengthen various work, such as teaching affair administration, logistic work, etc. The administrative staffs of school may not be familiar with the use of the management platform, so the training should be strengthened to acquire various knowledge of operation. Of course, with the development of the technology, management of platform will be more and more intelligent, and be divorced from the manual operation, which has great help for the daily management of colleges and universities, but may lead to the unemployment of management personnel.

\section{B. To establish educational information platform}

The characteristics of information explosion in big data era makes the software and platform for information processing popular, so the colleges and universities committed to cultivate talents should strengthen the education of information processing, in which the establishment of educational information platform is the best choice. Except the cultivation of network skills to students, manager and teacher can also improve their abilities by learning relevant knowledge on the platform. Information is becoming more and more important, so the establishment of educational information platform will be the development direction later.

\section{CONCLUSION}

The advent of the big data era promotes the transformation of society with both challenges and opportunities. In this case, both teachers and students can feel the changes brought by big data era, and students and teachers can keep on studying to improve their own abilities so as to adapt to the changes. Colleges and universities committed to cultivating talents should pay more attention to changing their teaching process and ways to cultivate the talents suitable for the society.

\section{REFERENCES}

[1] Hou Dawei, Yang Jiangfan. Study on the impact on educational innovation in big data era $[\mathrm{J}]$. Education Science \& Culture Magazine(first ten-day print), 2014, 12:3-4+11

[2] Lu Zhiyi. The belief crisis and reconstruction of teachers for ideological and political lessons of colleges and universities in big data era $[\mathrm{J}]$. Journal of Yanbian Institute of Education, 2014,06:16-20.

[3] Mi Huaquan, Song Xiao. Study on the network mechanism of ideological and political education of colleges and universities in big data era $[\mathrm{J}]$. Journal of Henan Polytechnic University (Social Science Edition), 2014,04:487-491

[4] Wu Ping. Impact and effect on college education in big data era [J]. Journal of Hubei University of Science and Technology, 2015,02:76-77+91

[5] Wang Haiyan, Cao Liying, Shao Xiwu. Study on the think tank construction of local colleges and universities in big data era $[\mathrm{J}]$. Information science, 2015,06:76-80.

[6] Chen Donghua. The influence and reflection on ideological and political education of colleges and universities in big data era $[\mathrm{J}]$. Electronic production, 2015,12:179.

[7] $\mathrm{Li} \mathrm{Fu}$. the development trend of world industry and its influence on higher vocational education in big data era $[\mathrm{J}]$. Education and occupation. 2015,18:14-17.

[8] Tao Wan, Yang Lei. Influence on the talent cultivation mode of colleges and universities in big data era-- take the information system major as an example [J]. Computer knowledge and technology, 2013,28:6340-6342+6347.

[9] Zhu Tongliu. Exploration on teaching reform of ideological and political lessons of colleges and universities in big data era $[\mathrm{J}]$. To learn theory, 2015,20:193-194.

[10] Liu Ailou. Interpretation and construction of ideological and political education mode of colleges and universities in big data era $[\mathrm{J}]$. Continuing education research, 2015,08:99-101.

[11] Zhou Jie. Impact and enlightenment on major construction of colleges and universities by the way of thinking in big data era $[\mathrm{J}]$. Human resource management, 2015,08:211-212.

[12] Wang Jing. The challenge and countermeasure analysis of student management work of colleges and universities in big data era $[\mathrm{J}]$. Study on ideological and political education, 2014,02:128-130.

[13] Wang Haijian. The effectiveness of ideological and political education of colleges and universities in big data era [J]. Journal of counselor in colleges and universities, 2014,04:37-40.

[14] Li Zhengyang. Study on the optimization of ideological and political education work of colleges and universities in big data era [J]. To learn theory, 2014,13:193-194. 